\title{
Studi Analysis Waktu Evakuasi Pada Kapal Penumpang Ferry Ro-ro 5000 GT Jalur Pelayaran Merak - Bakauheni
}

\author{
Nurhadi $* 1$ \\ ${ }^{1}$ Balai Teknologi Hidrodinamika, BPPT \\ Kampus ITS Keputih, Sukolilo - Surabaya, 60112 \\ *Email:nrhadi@gmail.com
}

DOI: 10.25042/jpe.052017.01

\begin{abstract}
Abstrak
Kapal Ferry Ro-ro merupakan jenis kapal penyeberangan yang banyak digunakan untuk transportasi antar pulau karena sangat cocok untuk angkutan kendaraan dan penumpang. Dengan semakin besar kapasitas angkut penumpang perlu diperhatikan pula prosedur jalur dan waktu evakuasi guna menghadapi keadaan darurat, hal ini sangat penting guna meminimalkan terjadinya korban jiwa. IMO telah mengeluarkan suatu regulasi untuk evakuasi dari berbagai tipe kapal dengan berbagai pendekatan analysis dimana nilai waktu evakuasi untuk jenis Ferry Ro-ro $\mathrm{n}<60$ menit. Pendekatan analysis evakuasi pada kapal Ferry Ro-ro 5000 GT untuk jalur pelayaran Merak - Bakauheni dilakukan dalam rangka untuk mengetahui seberapa besar waktu evakuasi yang dibutuhkan dengan membuat sebuah hydraulic diagram dengan metode simplified analysis serta advance analysis. Metode ini merupakan metode yang direkomendasikan IMO sebagaimana tertera dalam regulasi MSC.1/Circ.1238. Dari hasil analisa diketahui bahwa dengan simplified analysis didapatkan waktu evakuasi sebesar 34 menit 19 detik, sedang dengan advance analysis didapatkan waktu 29 menit 48 detik, sedangkan initial respon terhadap sinyal berkisar 180-240 detik.
\end{abstract}

Kata-kunci: Advance analysis, kapal ferry, regulasi, simplified analysis, waktu evakuasi

\begin{abstract}
Analysis study of Evacuation Time on 5000 GT Ferry Ro-Ro Passenger Ship of Merak - Bakauheni Route. Ferry Ro-ro is a type of ferry that is widely used for transportation that suitable for vehicle and passenger transportation. With the greater passenger capacity, the evacuation route and time is needed to deal with emergencies. That is very important to minimize casualties. IMO has issued a regulation for the evacuation of various ship types with various approaches analysis. The evacuation time value for Ferry Ro-ro type is $<60$ minutes. The evacuation analysis approach of Ferry Ro-ro 5000 GT vessel for the Merak - Bakauheni shipping line is done in order to find out how much evacuation time is needed, by making a hydraulic diagram, using simplified analysis and advance analysis. This method is recommended method from IMO as stated in MSC.1 / Circ. 1238 regulation. From result of the analysis known that with simplified analysis got evacuation time of 34 minutes 19 seconds, while advance analysis got time 29 minutes 48 seconds, and initial response to signal ranges 180-240 seconds.
\end{abstract}

Keywords: Advance analysis, ferry, regulation, simplified analysis, evacuation time

\section{Pendahuluan}

Jalur pelayaran Merak - Bakauheni merupakan salah satu jalur pelayaran yang cukup sibuk di Indonesia. Tercatat jumlah kendaraan yang melintas pada tahun 2016 pada saat sepi mencapai 4.000 unit hingga 6.000 unit kendaraan per hari, sementara disaat puncak kepadatan jumlah kendaraan bisa mencapai 11.000 unit lebih [1]. Salah satu upaya untuk mengurai kepadatan jalur tersebut, pemerintah mengembangankan Dermaga VI pelabuhan Bakauheni, disamping itu PT ASDP juga telah menambah 3 buah armada kapal Ferry Ro-ro dengan bobot mati 5000 GT [2].

Kapal Ferry Ro-ro ini merupakan jenis kapal penyeberangan antar pulau yang banyak digunakan karena disamping mampu menampung jumlah penumpang yang cukup banyak juga dapat dugunakan untuk mengangkut kendaraan seperti mobil, truk dan bis, sehingga kapal ini dilengkapi dengan pintu rampa baik pada sisi haluan maupun buritan.

Sesuai dengan standar regulasi IMO, bahwa untuk kapal penyeberangan antar pulau tidak boleh melampaui batas maksimal yang ditetapkan untuk 
evakuasi penumpang jika terjadi keadaan darurat. Sejumlah asumsi telah dikembangkan oleh banyak peneliti dalam mendukung keakuratan regulasi IMO tersebut diataranya: i) kecepatan berjalan, ii) arah pergerakan, iii) pergerakan orang diasumsikan tanpa rintangan, iv) pengaruh pergerakan kapal, umur penumpang, serta keterbatasan ruang gerak akibat asap, dan kesemuanya diperhitungkan melalui safety factor.

Berdasarkan pembahasan diatas, makalah ini akan membahas tentang studi analysis jalur evakuasi penumpang untuk mengetahui kemungkinan terjadinya titik -titik penumpukan penumpang pada jalur tertentu pada jalur evakuasi dan mengetahui seberapa besar waktu yang dibutuhkan untuk evakuasi penumpang pada kapal penyeberangan Ferry Ro-ro 5000 GT di atas.

\section{Dasar Teori}

Sejak Tahun 1970, IMO secara intensif mempublikasikan regulasi tentang evakuasi penumpang kapal laut, hal tersebut sesuai ketentuan SOLAS, kaitanya dengan keselamatan kapal dan jumlah pelampung penolong serta karakteristiknya.

Pada sesi ke 83 komite IMO (03-12 Oktober 2007), menyetujui pedoman pada evakuasi analisis untuk kapal penumpang baru dan yang sudah ada, termasuk kapal penumpang ro-ro, sebagaimana ditetapkan dalam MSC.1/Circ.1238 tanggal 30 Oktober 2007. Dalam pedoman ini menawarkan dua kriteria untuk analisa evakuasi meliputi [3]:

a. Analisis evakuasi yang disederhanakan (Simplified Evacuation Analysis)

b. Analisis evakuasi lanjutan (Advanced Evacuation Analysis)

\subsection{Simplified Evacuation Analysis}

Simplified Evacuation Analysis bertujuan untuk untuk menyajikan metodologi dalam melakukan analisis evakuasi yang disederhanakan khususnya, untuk: i). Mengidentifikasi dan menghilangkan sejauh mungkin kemacetan yang dapat berkembang selama evakuasi karena gerakan normal penumpang dan $\mathrm{ABK}$ di sepanjang rute evakuasi, mempertimbangkan kemungkinan bahwa ABK mungkin perlu untuk bergerak sepanjang rute-rute berlawanan dengan arah pergerakan penumpang. ii) Menunjukkan bahwa pengaturan evakuasi yang cukup fleksibel untuk menyediakan kemungkinan jalan keluar tertentu, tempat berkumpul, dan evakuasi kapal penyelamat, untuk menghindari korban akibat kegagalan evakuasi.

Definisi-definisi yang dipakai dalam perhitungan simplified analysis antara lain:

a. Persons load adalah jumlah orang yang dipertimbangkan dalam evakuasi.

b. Awareness time (A) adalah waktu yang dibutuhkan bagi orang untuk bereaksi terhadap situasi. Kali ini dimulai setelah pemberitahuan awal (misalnya, alarm) darurat dan berakhir ketika penumpang telah menerima situasi tersebut dan mulai bergerak menuju tempat berkumpul.

c. Travel time $(T)$ didefinisikan sebagai waktu yang dibutuhkan untuk semua orang di kapal untuk bergerak dari tempat mereka menuju tempat berkumpul (assembly station) kemudian ke tempat pemberangkatan (embarcations stations).

d. Embarcation time $(E)$ and launching time $(L)$, jumlah waktu yang dibutuhkan dari jumlah total orang untuk meninggalkan kapal.

Metode simplified analysis memperkirakan waktu evakuasi dasar secara umum oleh karena itu, asumsi analisis dibuat sebagai berikut:

1. Semua penumpang dan ABK akan mulai evakuasi pada saat yang sama dan tidak akan saling menghalangi satu sama lain.

2. Penumpang dan ABK akan mengevakuasi melalui rute pelarian utama, sebagaimana dimaksud dalam SOLAS regulasi II-13/2.

3. Kecepatan berjalan awal tergantung pada kepadatan orang, dengan asumsi bahwa aliran hanya ke arah jalan keluar, dan tidak saling mendahului.

4. Beban penumpang dan distribusi awal diasumsikan sesuai dengan pasal 13 dari kode FSS.

5. Ketersediaan penuh pengaturan melarikan diri dianggap, kecuali dinyatakan lain.

6. Orang dapat bergerak tanpa hambatan.

7. Counterflow dicatat oleh faktor koreksi counterflow.

8. Efek dari gerakan kapal, usia penumpang dan penurunan mobilitas, pengaturan fleksibilitas, tidak tersedianya koridor, visibilitas yang 
terbatas karena asap, diperhitungkan dalam faktor koreksi dan faktor keamanan. Faktor keamanan memiliki nilai 1.25 .

\subsection{Waktu Evakuasi}

Komponen-komponen berikut harus dipertimbangkan:

a. Waktu kesadaran (A) adalah 10 menit untuk skenario waktu malam dan 5 menit untuk skenario siang hari.

b. Metode untuk menghitung waktu perjalanan (T) diberikan dalam lampiran 1.

c. Waktu berkumpul (E) dan waktu peluncuran (L).

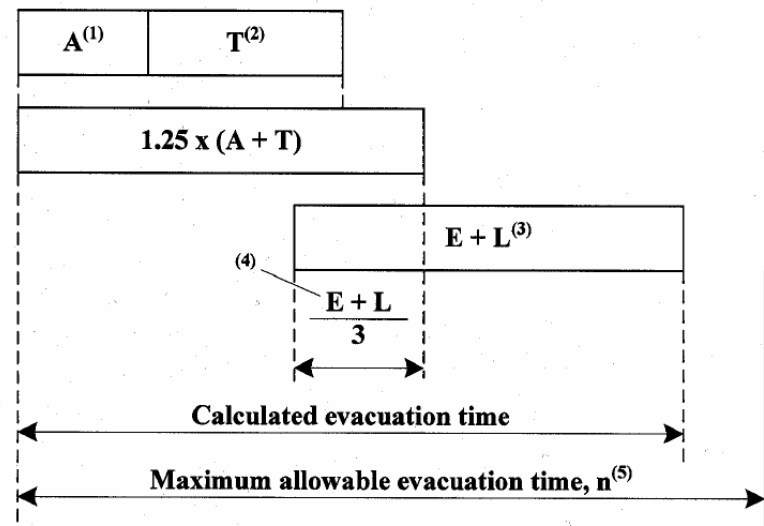

Gambar 1. Waktu evakuasi maksimum sesuai kriteria IMO 2007 [3].

Dimana:

a) 10 menit pada kasus 1 dan kasus 3, 5 menit untuk kasus 2 dan 4.

b) Dihitung berdasarkan pedoman pada lampiran 1

c) Maximum 30 menit sesuai dengan regulasi SOLAS III/21.1.4

d) Waktu overlap $=1 / 3(\mathrm{E}+\mathrm{L})$

e) Nilai maksimum n yang diijinkan

Total Evakuasi $=1.25(A+T)+2 / 3(E+L) \leq n$

$E+L \leq 30$ menit

Dimana:

- untuk kapal penumpang ro-ro, $n=60$; dan

- untuk kapal penumpang selain kapal penumpang ro-ro, $\mathrm{n}=60$ jika kapal memiliki tidak lebih dari tiga zona vertikal utama; dan 80, jika kapal memiliki lebih dari tiga zona vertikal utama.

Standar hubungan antara densitas (D) dari orang per meter ${ }^{2}$ pada rute evakuasi dengan specific flow (Fs) dan kecepatan gerak (S) dapat dilihat pada Tabel 1.
Tabel 1. Nilai specific flow dan speed sebagai fungsi dari density

\begin{tabular}{lccc}
\hline \multirow{3}{*}{ Type } & $\begin{array}{c}\text { Initial } \\
\text { Density }\end{array}$ & $\begin{array}{c}\text { Initial } \\
\text { Specific } \\
\text { Flow }\end{array}$ & $\begin{array}{c}\text { Initial Speed of } \\
\text { Persons }\end{array}$ \\
\cline { 2 - 4 } & $\mathrm{D}\left(\mathrm{p} / \mathrm{m}^{2}\right)$ & Fs $(\mathrm{p} /(\mathrm{ms}))$ & $\mathrm{S}(\mathrm{m} / \mathrm{s})$ \\
\cline { 2 - 4 } Corridor & 0 & 0 & 1.2 \\
\cline { 2 - 4 } & 0.5 & 0.65 & 1.2 \\
\cline { 2 - 4 } & 1.9 & 1.3 & 0.67 \\
\cline { 2 - 4 } & 3.2 & 0.65 & 0.2 \\
\hline
\end{tabular}

Tabel 2. Nilai maksimum specific flow pada masingmasing tipe tempat

\begin{tabular}{lc}
\hline \multirow{2}{*}{ Type } & Maksimum Specific Flow \\
\cline { 2 - 2 } & Fs $(\mathrm{p} /(\mathrm{ms}))$ \\
\hline Stairs (down) & 1.1 \\
\hline Stairs (up) & 0.88 \\
\hline Corridor & 1.3 \\
\hline Doorways & 1.3 \\
\hline
\end{tabular}

Tabel 3. Nilai maksimum specific flow dan speed pada masing-masing tipe tempat

\begin{tabular}{ccc}
\hline \multirow{2}{*}{ Type } & Specific Flow & Initial Speed of Persons \\
\cline { 2 - 3 } & Fs $(\mathrm{p} /(\mathrm{ms}))$ & $\mathrm{S}(\mathrm{m} / \mathrm{s})$ \\
\hline \multirow{2}{*}{$\begin{array}{c}\text { Stairs } \\
\text { (down) }\end{array}$} & 0 & 1 \\
\cline { 2 - 3 } & 0.54 & 1 \\
\hline \multirow{3}{*}{ Stairs (up) } & 1.1 & 0.55 \\
& 0 & 0.8 \\
\cline { 2 - 3 } & 0.43 & 0.8 \\
\hline \multirow{3}{*}{ Corridor } & 0.88 & 0.44 \\
\cline { 2 - 3 } & 0 & 1.2 \\
\cline { 2 - 3 } & 0.65 & 1.2 \\
\hline
\end{tabular}

Sumber : IMO MSC/Circ. 1238 [3].

Nilai calculated flow of persons $(\mathrm{Fc})$ dapat dihitung dengan rumus :

$$
\mathrm{Fc}=\mathrm{Fs} \mathrm{Wc}
$$

Dimana Fs adalah specific flow dan Wc adalah clear width dari area yang dihitung. Sedangkan Flow time $\left(\mathrm{t}_{\mathrm{f}}\right)$ adalah perbandingan jumlah orang dengan calculated flownya, sehingga :

$$
t_{f}=N / F_{C}
$$




\subsection{Advance Evacuation Analysis}

Pathfinder adalah salah satu software simulasi jalur evakuasi yang berdasarkan agen dan gerakan simulator manusia. Software ini menyediakan antarmuka pengguna grafis untuk desain simulasi serta visualisasi 2D dan 3D untuk analisis hasil.

GUI pada pathfinder digunakan terutama untuk membuat dan menjalankan model simulasi. Sebuah screenshot dari antarmuka pengguna ini ditunjukkan pada Gambar 2.

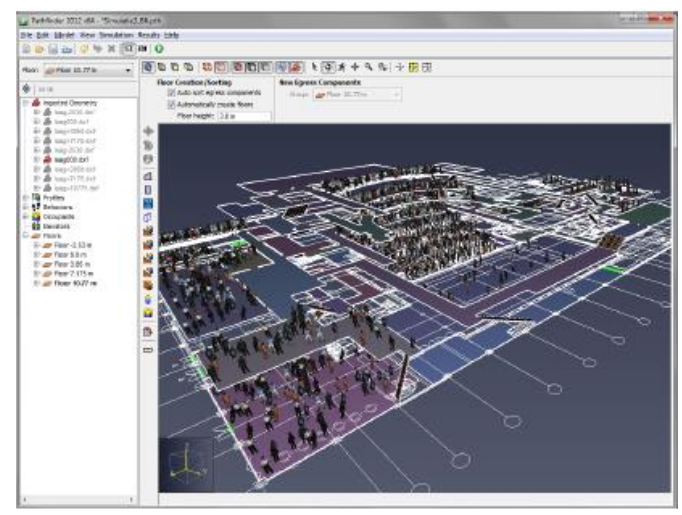

Gambar 2. Screenshot pathfinder.

Pathfinder juga mencakup program kedua yang dirancang khusus untuk visualisasi kinerja tinggi dari waktu secara 3D. 3D program hasil ditunjukkan pada Gambar 3. Pada Gambar 3, penumpang berkumpul di area perlindungan sebelum melanjutkan ke lift. Transparansi dari program digunakan untuk membantu pandangan penumpang terhadap dinding pelindung.

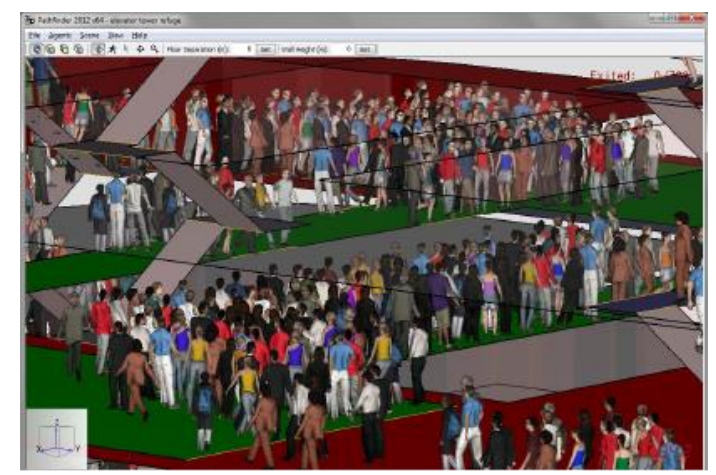

Gambar 3. Screenshot visualisasi pada pathfinder.

Lingkungan gerakan adalah mesh 3D, dirancang agar sesuai dengan dimensi nyata dari sebuah model bangunan. Mesh gerakan dapat dimasukkan secara manual atau secara otomatis berdasarkan data impor (misalnya FDS geometri).

Dinding dan daerah lain direpresentasikan sebagai gap dalam mesh navigasi. Benda-benda ini tidak benar-benar diteruskan ke simulator, tapi diwakili implisit karena penumpang tidak bisa bergerak di tempat-tempat di mana tidak ada jalan navigasi yang telah dibuat.

Pintu direpresentasikan sebagai tepi khusus mesh navigasi. Dalam semua simulasi, pintu menyediakan mekanisme untuk menggabungkan kamar dan jalur pencarian aliran penumpang. Bergantung pada pilihan tertentu dari simulasi, pintu juga dapat digunakan secara eksplisit untuk mengontrol aliran penumpang.

Tangga direpresentasikan sebagai ujung navigasi, jalan khusus dan bentuk segitiga. Kecepatan gerak penumpang dikurangi dengan faktor kecepatan perjalanan berdasarkan tingkat kemiringan dari tangga. Setiap tangga secara implisit mendefinisikan dua pintu. Pintu-pintu ini berfungsi sama seperti pintu lainnya di simulator, tetapi dikendalikan melalui editor tangga untuk memastikan bahwa tidak ada kesalahan geometrik dari ketidaksesuaian antara tangga dan pintu penghubung.

Penumpang diwakili sebagai silinder tegak pada pergerakannya dan gerakannya menggunakan teknik berbasis agen. Setiap penumpang mempunyai gerakan yang independen tidak bergantung satu dengan yang lain.

Dalam mode SFPE, penumpang tidak berusaha untuk menghindari satu sama lain dan diperbolehkan untuk saling merasuk, tapi pintu membatasi adanya batas aliran dan kecepatan yang dikendalikan oleh kepadatan dari penumpang [4].

\section{Metodologi}

Metodologi yang digunakan dalam penelitian ini adalah studi pustaka dan simulasi perhitungan berdasarkan hasil studi pustaka baik secara simplified analysis dan advance analysis.

Langkah-langkah yang dilakukan dalam metodologi ini meliputi:

1. Pengumpulan data-data utama kapal meliputi jumlah penumpang dan sebarannya berdasarkan general arrangement kapal Ferry Ro-ro 5000 GT.

2. Dilakukan pengukuran masing-masing ruang dan jalur evakuasi baik pintu, corridor, area dan tangga.

3. Pengamatan dan penentuan titik muster point yang paling memungkinkan dalam evakuasi. 
4. Perencanaan diagram hidrolik evakuasi

5. Simulasi dan perhitungan serta analisa kesimpulan

\section{Hasil dan Pembahasan}

Untuk penerapan simplified analysis evacuation serta advance analysis evacuation dalam perhitungannya perlu diketahui data-data kapal, general arrangement dan safety plant-nya. Kapal penumpang Ro-ro 5000 GT milik ASDP yang digunakan dalam pelayaran Merak Bakahuni memiliki data sebagai berikut:

4.1. Data dan spesifikasi kapal:

- $\quad$ Panjang keseluruhan (Loa) : 109,40 m

- Panjang antara garis tegak (Lpp) : 99,20 m

- Lebar (moulded) (Bmid) : 19,60 m

- Tinggi (moulded) (Hmid) : 5,60 m

- Sarat air d:4,10 m

- Gross Tonnage (GT) : 5330 GT

- Kecepatan dinas (Vs) : 15.00 knot

Kapasitas angkut kapal adalah:

\section{a. Penumpang}

Penumpang kelas VIP: 18 orang (dek penumpang 02), penumpang dek terbuka: 232 orang (dek penumpang 02), penumpang dek kursi baring: 324 orang (dek penumpang 01), penumpang kelas kursi sofa: 140 orang (dek penumpang 01), penumpang dek kafetaria: 98 orang (dek penumpang 01).

b. Formasi kendaraan maksimum

Trailer 40 feet: 26 unit, tronton 10 roda: 2 unit, truk medium: 37 unit, sedan: 77 unit.

Untuk memenuhi ketentuan SOLAS, perlengkapan keselamatan jiwa (life saving appliances) yang terpasang di kapal antara lain:

- Rescue boat (dilengkapi engine 230 HP): 2 unit (kap@18 pax).

- $\quad$ Marine Evacuation System (MES): 2 unit (kap @600 pax/30 menit).

- Inflatable Life Raft (ILR): 24 unit (kap @ 50 pax).

- Life jacket: 1080 set.

- Life buoy (ring penyelamat): 22 unit.

- Dan peralatan lain sesuai dengan regulasi LSA/SOLAS.

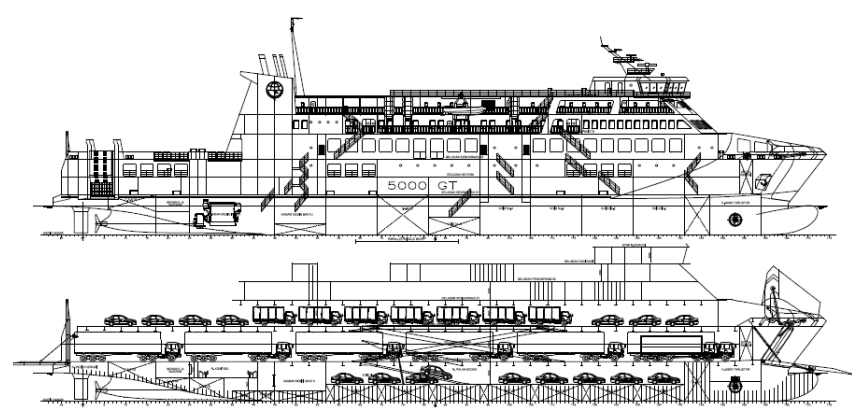

Gambar 4. General arrangement kapal Ro-ro 5000 GT.

\subsection{Skenario}

Untuk perhitungan simplified analysis evacuation kali ini diambil suatu skenario evakuasi pada siang hari (case 2) dimana dibuat beberapa asumsi yang disederhanakan meliputi:

a. Titik muster point ditentukan pada dek penumpang 01, dimana sebelumnya terdapat 324 penumpang yang berada di tempat tersebut.

b. Sebaran evakuasi penumpang dianggap merata pada sisi PortSide dan StarBoard sehingga jumlah penumpang pada area terbagi menjadi dua.

c. Penumpang pada dek kafetaria (dek penumpang 01) dibagi dalam area 3 dan area 4 dengan masing-masing 47 penumpang.

d. Penumpang dek kursi sofa (dek penumpang 01) dibagi dalam area 5 dan area 6 dengan masingmasing 70 penumpang.

e. Penumpang dek terbuka: 232 orang (dek penumpang 02), diasumsikan terbagi dalam area 1 dan area 2 dengan masing-masing 116 penumpang.

Dari gambar general arrangement Ferry Ro-ro 5000 GT, diketahui bahwa sebaran penumpang terdapat pada dek penumpang 01 dan dek penumpang 02 sehingga dibuat suatu rencana jalur evakuasi sebagai berikut:
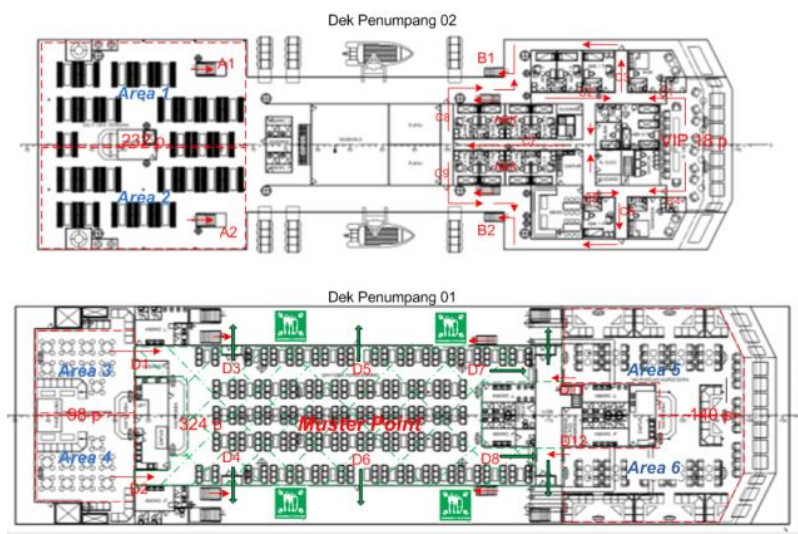

Gambar 5. Rencana jalur evakuasi. 
Dari rencana jalur evakuasi tersebut dapat dibuat sebuah skema hidrolik sistemnya sebagai berikut :

\section{A. Penumpang yang menuju Muster Point}

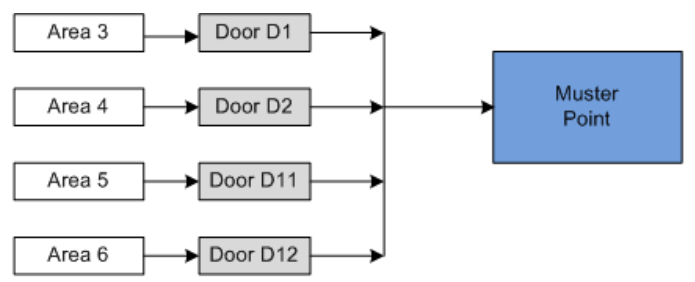

Dek Penumpang 01 (DP 01)

B. Penumpang yang langsung ke Embarcation Point (dek terbuka)

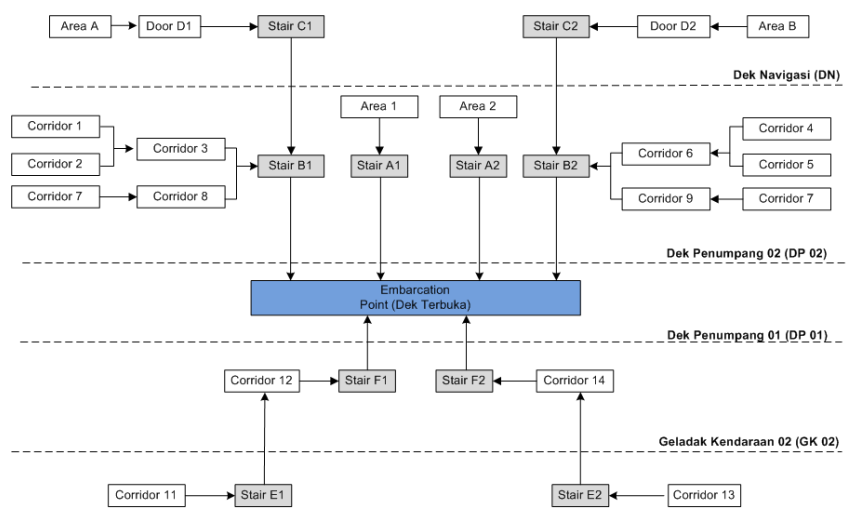

Gambar 6. Model hidrolik jalur evakuasi.

(A) Penumpang yang langsung menuju muster point pada dek penumpang 01. (B) Penumpang yang langsung menuju embarcation point.

\subsection{Metode Simplified Analysis}

\subsubsection{Perhitungan $t_{f}, t_{\text {dek }}$ dan $t_{\text {stair }}$}

Berdasarkan data perhitungan pada tabel rute yang dibuat maka dapat dihitung flow time $\left(\mathrm{t}_{\mathrm{f}}\right)$, waktu untuk tangga $\left(\mathrm{t}_{\text {stair }}\right)$ dan waktu pergerakan di dek $\left(t_{\text {dek }}\right)$. Hasil perhitungan dapat dilihat pada Tabel 5, untuk masing-masing jalur.

Tabel 5. Hasil perhitungan $\mathbf{t}_{\mathbf{f}}, \mathbf{t}_{\mathrm{dek}}$ dan $\mathbf{t}_{\text {stair }}$

\begin{tabular}{lccccccc}
\hline \multicolumn{1}{c}{ Item } & $(\mathrm{N})$ & $\mathrm{L}(\mathrm{m})$ & $\begin{array}{c}\mathrm{Fc} \\
(\mathrm{p} / \mathrm{s})\end{array}$ & $\begin{array}{c}\mathrm{S} \\
(\mathrm{m} / \mathrm{s})\end{array}$ & $\begin{array}{c}\mathrm{t}_{\mathrm{f}} \\
\mathrm{N} / \mathrm{Fc}\end{array}$ & $\begin{array}{c}\mathrm{t}_{\mathrm{dek}}, \\
\mathrm{t}_{\mathrm{stair}} \\
\mathrm{L} / \mathrm{S}\end{array}$ & to \\
\hline DN-area A & 3 & 3.33 & 1.17 & 1.20 & 2.57 & 2.78 & $\begin{array}{c}\text { door } \\
\mathrm{D} 1\end{array}$ \\
\hline DN -Area B & 3 & 3.33 & 1.17 & 1.20 & 2.57 & 2.78 & $\begin{array}{c}\text { door } \\
\mathrm{D} 2\end{array}$ \\
\hline $\begin{array}{l}\text { DN - Door } \\
\text { D1 }\end{array}$ & 3 & N.A & 0.78 & N.A & 3.85 & N.A & $\begin{array}{c}\text { Stair } \\
\mathrm{C} 1\end{array}$ \\
\hline DN - Door & 3 & N.A & 0.78 & N.A & 3.85 & N.A & $\begin{array}{c}\text { Stair } \\
\text { C2 }\end{array}$ \\
$\begin{array}{l}\text { D2 } \\
\text { DN - Stair }\end{array}$ & 3 & 2.97 & 0.80 & 0.63 & 3.75 & 4.71 & $\begin{array}{c}\text { Stair } \\
\text { B1 }\end{array}$ \\
\hline
\end{tabular}

\begin{tabular}{|c|c|c|c|c|c|c|c|}
\hline $\begin{array}{l}\text { DN - Stair } \\
\mathrm{C} 2\end{array}$ & 3 & 2.97 & 0.80 & 0.63 & 3.75 & 4.71 & $\begin{array}{l}\text { Stair } \\
\text { B2 }\end{array}$ \\
\hline $\begin{array}{l}\text { DP02-Area } \\
1\end{array}$ & 116 & 19.60 & 8.51 & 1.13 & 13.62 & 17.35 & $\begin{array}{c}\text { Stair } \\
\text { A1 }\end{array}$ \\
\hline $\begin{array}{l}\text { DP02-Area } \\
2\end{array}$ & 116 & 19.60 & 8.51 & 1.13 & 13.62 & 17.35 & $\begin{array}{l}\text { Stair } \\
\text { A2 }\end{array}$ \\
\hline $\begin{array}{l}\text { DP02-Stair } \\
\text { A1 }\end{array}$ & 116 & 4.00 & 1.10 & 0.55 & 105.45 & 7.27 & ED \\
\hline $\begin{array}{l}\text { DP02-Stair } \\
\text { A2 }\end{array}$ & 116 & 4.00 & 1.10 & 0.55 & 105.45 & 7.27 & ED \\
\hline DP02-corr 1 & 18 & 3.65 & 0.11 & 0.10 & 163.64 & 36.50 & Corr 3 \\
\hline DP02-corr 2 & 3 & 8.00 & 0.24 & 1.20 & 12.34 & 6.67 & Corr 3 \\
\hline DP02-corr 3 & 21 & 3.95 & 1.06 & 0.95 & 19.89 & 4.16 & $\begin{array}{c}\text { Stair } \\
\text { B1 }\end{array}$ \\
\hline DP02-corr 4 & 13 & 3.65 & 0.83 & 1.12 & 15.76 & 3.26 & Corr 6 \\
\hline DP02-corr 5 & 7 & 3.00 & 0.56 & 1.20 & 12.55 & 2.50 & Corr 6 \\
\hline DP02-corr 6 & 20 & 3.95 & 1.02 & 0.97 & 19.55 & 4.07 & $\begin{array}{l}\text { Stair } \\
\text { B2 }\end{array}$ \\
\hline DP02-corr 7 & 16 & 12.12 & 0.91 & 1.05 & 17.52 & 11.54 & $\begin{array}{l}\text { Corr } \\
8,9\end{array}$ \\
\hline DP02-corr 8 & 8 & 3.80 & 0.68 & 1.20 & 11.70 & 3.17 & $\begin{array}{c}\text { Stair } \\
\text { B1 }\end{array}$ \\
\hline DP02-corr 9 & 8 & 3.80 & 0.68 & 1.20 & 11.70 & 3.17 & $\begin{array}{c}\text { Stair } \\
\text { B2 }\end{array}$ \\
\hline $\begin{array}{l}\text { DP02-Stair } \\
\text { B1 }\end{array}$ & 31 & 4.00 & 0.88 & 0.55 & 35.23 & 7.27 & ED \\
\hline $\begin{array}{l}\text { DP02-Stair } \\
\text { B2 }\end{array}$ & 32 & 4.00 & 0.88 & 0.55 & 36.36 & 7.27 & ED \\
\hline $\begin{array}{l}\text { DP01-Area } \\
3\end{array}$ & 49 & 8.50 & 5.21 & 1.03 & 9.40 & 8.25 & $\begin{array}{c}\text { Door } \\
\text { D1 }\end{array}$ \\
\hline $\begin{array}{l}\text { DP01-Area } \\
4\end{array}$ & 49 & 8.50 & 5.21 & 1.03 & 9.40 & 8.25 & $\begin{array}{c}\text { Door } \\
\text { D2 }\end{array}$ \\
\hline $\begin{array}{l}\text { DP01-Area } \\
5\end{array}$ & 70 & 13.50 & 5.25 & 1.10 & 13.33 & 12.27 & $\begin{array}{l}\text { Door } \\
\text { D11 }\end{array}$ \\
\hline $\begin{array}{l}\text { DP01-Area } \\
6\end{array}$ & 70 & 13.50 & 5.25 & 1.10 & 13.33 & 12.27 & $\begin{array}{l}\text { Door } \\
\text { D12 }\end{array}$ \\
\hline DP01-D1 & 49 & N.A & 1.56 & N.A & 31.41 & N.A & $\begin{array}{c}\text { Muster } \\
\text { Point }\end{array}$ \\
\hline $\begin{array}{l}\text { DP01-Door } \\
\text { D2 }\end{array}$ & 49 & N.A & 1.56 & N.A & 31.41 & N.A & $\begin{array}{c}\text { Muster } \\
\text { Point }\end{array}$ \\
\hline $\begin{array}{l}\text { DP01-Door } \\
\text { D11 }\end{array}$ & 70 & N.A & 1.56 & N.A & 44.87 & N.A & $\begin{array}{c}\text { Muster } \\
\text { Point }\end{array}$ \\
\hline $\begin{array}{l}\text { DP01-Door } \\
\text { D12 }\end{array}$ & 70 & N.A & 1.56 & N.A & 44.87 & N.A & $\begin{array}{c}\text { Muster } \\
\text { Point }\end{array}$ \\
\hline $\begin{array}{l}\text { GK 02-corr } \\
12\end{array}$ & 4 & 7.27 & 0.72 & 1.20 & 5.55 & 6.06 & $\begin{array}{c}\text { Stair } \\
\text { F1 }\end{array}$ \\
\hline $\begin{array}{l}\text { GK 02-corr } \\
14\end{array}$ & 4 & 7.27 & 0.72 & 1.20 & 5.55 & 6.06 & $\begin{array}{c}\text { Stair } \\
\text { F2 }\end{array}$ \\
\hline $\begin{array}{l}\text { GK 02-Stair } \\
\text { F1 }\end{array}$ & 4 & 5.50 & 0.88 & 0.88 & 4.55 & 6.25 & ED \\
\hline $\begin{array}{l}\text { GK 02-Stair } \\
\text { F2 }\end{array}$ & 4 & 5.50 & 0.88 & 0.88 & 4.55 & 6.25 & ED \\
\hline GA-corr 11 & 4 & 2.55 & 1.45 & 1.04 & 2.77 & 2.45 & $\begin{array}{c}\text { Stair } \\
\text { E1 }\end{array}$ \\
\hline GA-corr 13 & 4 & 2.55 & 1.45 & 1.04 & 2.77 & 2.45 & $\begin{array}{c}\text { Stair } \\
\text { E2 }\end{array}$ \\
\hline GA-Stair E1 & 4 & 3.45 & 0.88 & 0.88 & 4.55 & 3.92 & $\begin{array}{c}\text { Corr } \\
12 \\
\end{array}$ \\
\hline GA-Stair E2 & 4 & 3.45 & 0.88 & 0.88 & 4.55 & 3.92 & $\begin{array}{c}\text { Corr } \\
14\end{array}$ \\
\hline
\end{tabular}

\subsubsection{Perhitungan waktu assembly}

Pada perhitungan waktu assembly seperti yang tertera pada Tabel 6, digunakan 2 model assembly dimana untuk tabel Model A dari muster point ke titik assembly, penumpang melalui pintu D3-D8 
dengan 3 titik assembly pada sisi PS dan 3 pada sisi $\mathrm{SB}$, dimana penumpang terbagi merata.

Tabel 6. Hasil perhitungan waktu assembly Model A

\begin{tabular}{cccccccc} 
Item & $(\mathrm{N})$ & $\mathrm{L}(\mathrm{m})$ & $\begin{array}{c}\mathrm{Fc} \\
(\mathrm{p} / \mathrm{s})\end{array}$ & $\begin{array}{c}\mathrm{S} \\
(\mathrm{m} / \mathrm{s})\end{array}$ & $\begin{array}{c}\mathrm{t}_{\mathrm{f}} \\
\mathrm{N} / \mathrm{Fc}\end{array}$ & $\begin{array}{c}\mathrm{t}_{\mathrm{dek}} \\
\mathrm{L} / \mathrm{S}\end{array}$ & To \\
\hline DP01- D3 & 110 & 3.00 & 1.22 & 1.2 & 90.06 & 2.5 & Ass.st \\
\hline DP01- D4 & 110 & 3.00 & 1.22 & 1.2 & 90.06 & 2.5 & Ass.st \\
\hline DP01- D5 & 70 & 5.90 & 0.77 & 1.2 & 90.06 & 4.9 & Ass.st \\
\hline DP01- D6 & 70 & 5.90 & 0.77 & 1.2 & 90.06 & 4.9 & Ass.st \\
\hline DP01- D7 & 101 & 9.40 & 1.12 & 1.2 & 90.06 & 7.8 & Ass.st \\
\hline DP01- D8 & 101 & 9.40 & 1.12 & 1.2 & 90.06 & 7.8 & Ass.st \\
\hline
\end{tabular}

Pada Model B, titik assembly dianggap hanya pada sisi PS dan SB saja secara memanjang, sehingga penumpang di muster point terbagi menjadi 2, sebagaimana ditunjukkan pada Tabel 7.

Tabel 7. Hasil perhitungan waktu assembly Model B

\begin{tabular}{cccccccc} 
Item & $(\mathrm{N})$ & $\mathrm{L}(\mathrm{m})$ & $\begin{array}{c}\mathrm{Fc} \\
(\mathrm{p} / \mathrm{s})\end{array}$ & $\begin{array}{c}\mathrm{S} \\
(\mathrm{m} / \mathrm{s})\end{array}$ & $\begin{array}{c}\mathrm{t}_{\mathrm{f}} \\
\mathrm{N} / \mathrm{Fc}\end{array}$ & $\begin{array}{c}\mathrm{t}_{\text {dek }} \\
\mathrm{L} / \mathrm{S}\end{array}$ & $\mathrm{To}$ \\
\hline DP01- SB & 281 & 18.3 & 3.12 & 1.0 & 15.3 & 16.9 & Ass \\
\hline DP01- PS & 281 & 15.4 & 3.12 & 1.0 & 18 & 14.2 & Ass \\
\hline
\end{tabular}

\subsubsection{Perhitungan nilai $\mathrm{T}$}

Perhitungan waktu $\mathrm{T}$ berdasarkan petunjuk IMO diambil dari waktu maksimum t1, dikalikan dengan 2.3 (sebagai faktor koreksi), sehingga nilai maksimum waktu $\mathrm{T}$ dari masing-masing rute dapat dilihat pada Tabel 8 .

Tabel 8: Hasil perhitungan waktu evakuasi

\begin{tabular}{cccccccc}
\hline Escape route & $\mathrm{t}_{\text {dek }}$ & $\mathrm{t}_{\mathrm{f}}$ & $\mathrm{T}_{\text {stair }}$ & $\mathrm{T}_{\text {ass }}$ & $\mathrm{t} 1$ & $\mathrm{~T}$ & Note \\
\hline DN-Stair C1 & 2.78 & 45.40 & 11.99 & 0 & 60.16 & 138.4 & 1,2 \\
\hline DN-Stair C2 & 2.78 & 46.53 & 11.99 & 0 & 61.30 & 141.0 & 1,2 \\
\hline DP02-Stair A1 & 17.35 & 119.08 & 7.27 & 0 & 143.70 & 330.5 & 1,2 \\
\hline DP02-Stair A2 & 17.35 & 119.08 & 7.27 & 0 & 143.70 & 330.5 & 1,2 \\
\hline DP02-Stair B1 & 40.66 & 64.45 & 7.27 & 0 & 112.38 & 258.5 & 1,2 \\
\hline DP02-Stair B2 & 14.71 & 65.58 & 7.27 & 0 & 87.57 & 201.4 & 1,2 \\
\hline DP01 (model A) & 12.27 & 148.27 & 0.00 & 7.8 & 168.37 & 387.2 & 1,3 \\
\hline DP01 (model B) & 0 & 73.56 & 0.00 & 16.9 & 90.50 & 208.2 & 1,3 \\
\hline GK 02-Stair F1 & 6.06 & 10.09 & 6.25 & 0 & 22.40 & 51.5 & 1,2 \\
\hline GK 02-Stair F2 & 6.06 & 10.09 & 6.25 & 0 & 22.40 & 51.5 & 1,2 \\
\hline GA-Stair E1 & 2.45 & 17.41 & 10.17 & 0 & 30.03 & 69.1 & 1,2 \\
\hline GA-Stair E2 & 2.45 & 17.41 & 10.17 & 0 & 30.03 & 69.1 & 1,2 \\
\hline
\end{tabular}

Note:

1. Flow time $\left(\mathrm{t}_{\mathrm{f}}\right)$ adalah waktu maksimum yang terhitung pada rute jalur evakuasi darimana dek orang tersebut berasal dan mulai dievakuasi.

2. Nilai t assembly dianggap 0 karena orang-orang telah mencapai titik embarcation point sehingga tidak dibutuhkan waktu untuk mencapai titik assembly station. (lihat MSC.1/Circ.1238 hal 24).

3. Total waktu pergerakan pada tangga ( $\left.\mathrm{t}_{\text {stair }}\right)$ adalah total waktu yang dibutuhkan untuk bergerak pada tangga yang dilewati mulai dari dek berasal sampai dek dimana muster point berada.

Dari hasil perhitungan dengan metode simplified didapatkan nilai $\mathrm{T}$ terbesar adalah $\mathbf{3 8 7 . 2}$ detik, maka pada case siang hari dipakai nilai awarness adalah 5 menit dan nilai $\mathrm{E}+\mathrm{L}$ diasumsikan 30 menit sehingga:

$$
\begin{aligned}
& 1.25 *(\mathrm{~A}+\mathrm{T})+2 / 3(\mathrm{E}+\mathrm{L}) \\
& 1.25 *\left(6^{\prime} 27^{\prime}{ }^{\prime}+5\right)+2 / 3(30)=34^{\prime} 19^{\prime},
\end{aligned}
$$

Nilai n yang didapatkan 34 menit 19 detik.

\subsection{Metode Advance Analysis}

Ada beberapa tahapan yang harus dilakukan untuk mensimulasikan dengan software pathfinder dimana dalam simulasi ini ada beberapa asumsi yang digunakan antara lain :

a. Karena sebaran penumpang terbanyak terdapat pada dek penumpang 01 dan dek penumpang 02 maka simulasi difokuskan pada area tersebut, sehingga untuk simulasi hanya akan dibuat dek navigasi, dek penumpang 02 dan dek penumpang 01 .

b. Untuk dek pada geladak antara dengan 4 orang ABK tidak dibuat simulasi karena berdasar simplified evacuation waktu $\mathrm{T}$ yang dibutuhkan menuju embarcation point sangat kecil sehingga tidak berpengaruh.

c. Metode simulasi yang akan digunakan adalah dengan SFPE.

Untuk langkah-langkah persiapan yang dilakukan antara lain:

a. Persiapan atau pembuatan model uji dengan pathfinder. Pada tahap ini dilakukan penggambaran 3D kapal dan ruangan penumpang serta jalur, tangga, dan pintu.

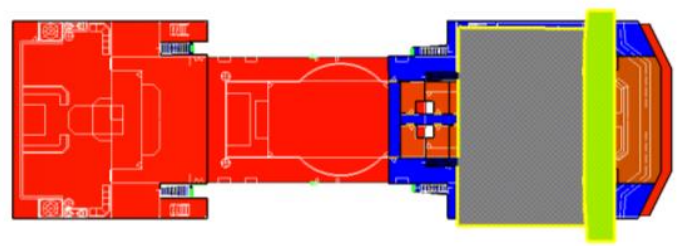

Gambar 7. Pemodelan pada pathfinder. 


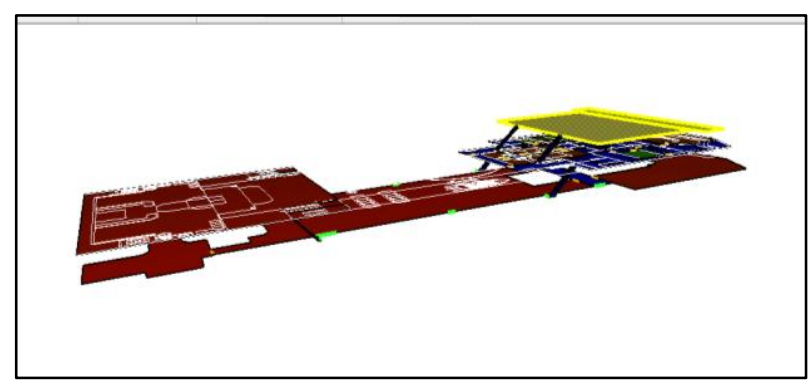

Gambar 8. Pemodelan pada pathfinder.

b. Penetapan jumlah sebaran occupants atau penumpang pada masing-masing ruangan atau area sesuai dengan data yang ada.

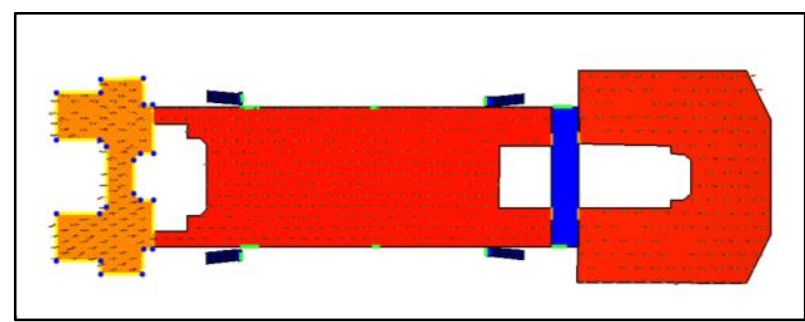

Gambar 9. Sebaran penumpang dek penumpang 01.

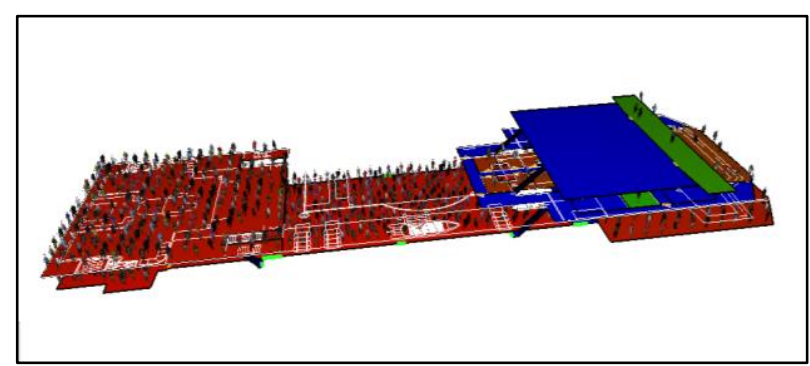

Gambar 10. Sebaran penumpang dek penumpang 01, dek penumpang 02, dan dek navigasi.

Pengecekan jika terjadi error pada gambar yang dibuat, dimana akan muncul tanda error pada menu sebelah kiri.

\subsubsection{Simulasi (SFPE Mode)}

Dalam SFPE mode, penumpang mengikuti aturan yang dijelaskan dalam panduan SFPE: kecepatan penumpang adalah fungsi kepadatan ruang, penumpang dapat menempati ruang yang sama, dan laju aliran melalui pintu didasarkan pada SFPE. Mode ini memberikan hasil dasar sesuai kasus dengan solusi yang diakui. Pilihan analisis ini adalah komputasi cepat.

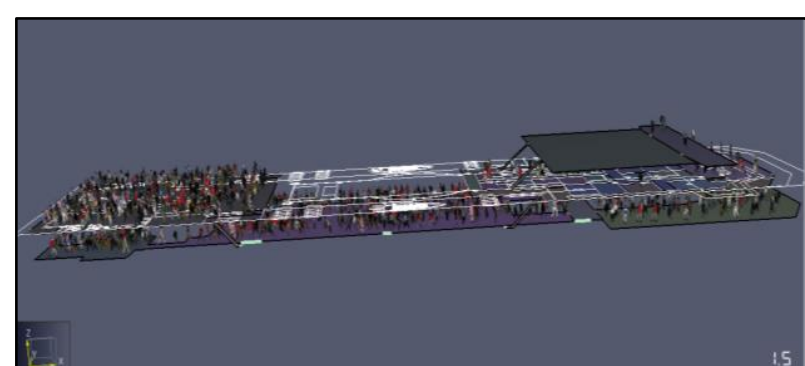

Gambar 11. View 3D running hasil simulasi.

Untuk jumlah sebaran penumpang mengacu dari IMO, akan tetapi penyandang cacat dianggap tidak ada/dihilangkan, dengan initial respon time antara 180 - 240 detik, distribusi log normal dengan rata-rata 210 detik, sehingga sebaran penumpang adalah sebagai berikut :

\begin{tabular}{cc}
\hline Penumpang & Jumlah $\%$ \\
\hline Female $<30$ & 14 \\
\hline Female 30-50 & 14 \\
\hline Female $>50$ & 22 \\
\hline Male $<30$ & 14 \\
\hline Male 30-50 & 14 \\
\hline Male $>50$ & 22 \\
\hline
\end{tabular}

Dengan pembagian route penumpang dibuat seperti pada metode simplified evacuation. Dari hasil running program didapatkan:

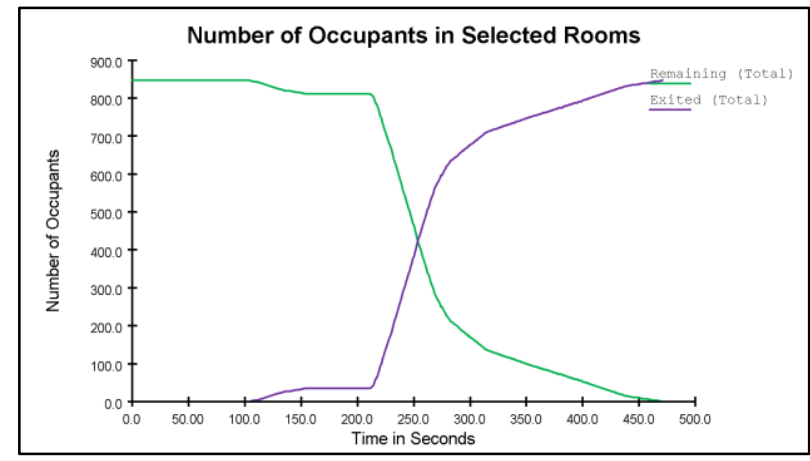

Gambar 13. Grafik jumlah penumpang dan waktu yang dibutuhkan untuk meninggalkan ruangan.

Dari grafik Gambar 13, terlihat bahwa waktu yang dibutuhkan paling lama dari penumpang adalah 470.6 detik. 


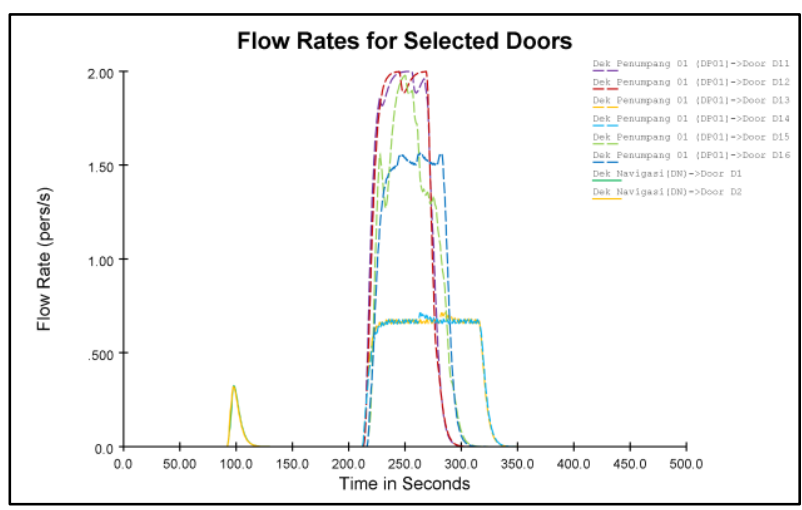

Gambar 14. Grafik flow rates masing-masing pintu.

Dari flow rate Gambar 14, terlihat bahwa pintu paling banyak digunakan adalah pintu D11 dan D12, dimana mencapai 2 persons/detik, hal ini dimungkinkan karena posisi pintu keluar yang dekat dengan kerumunan penumpang pada dek penumpang 01 .

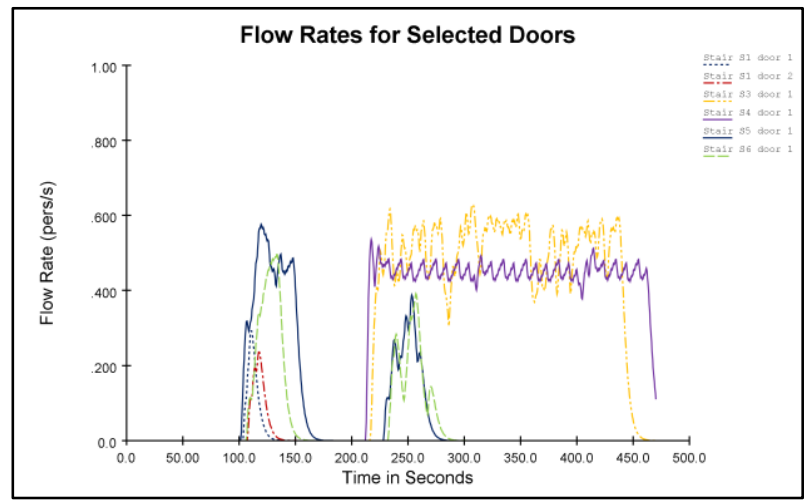

Gambar 15. Grafik flow rates masing-masing tangga.

Dari flow rate tangga terlihat bahwa tangga paling banyak digunakan adalah tangga S3 dan S4, dimana mencapai 0.6 persons/detik, selama kurun waktu 309 detik, hal disebabkan tangga tersebut merupakan jalur dari area 1 dan area 2 dengan jumlah penumpang pada area tersebut mencapai 232 orang.

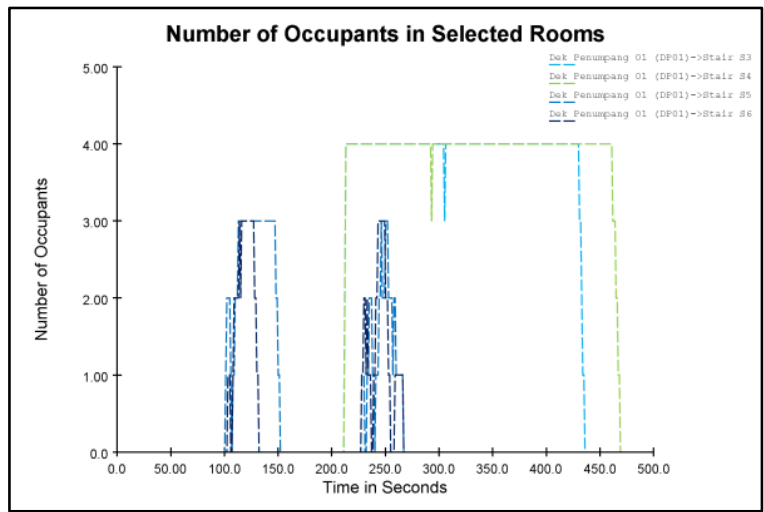

Gambar 16. Grafik jumlah penumpang dan waktu pada masing-masing tangga di dek penumpang 01.

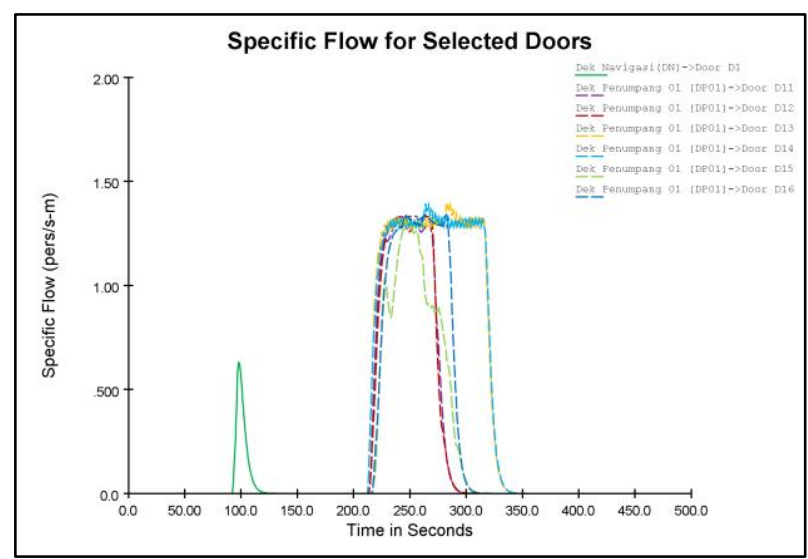

Gambar 17. Grafik specific flow masing-masing pintu.

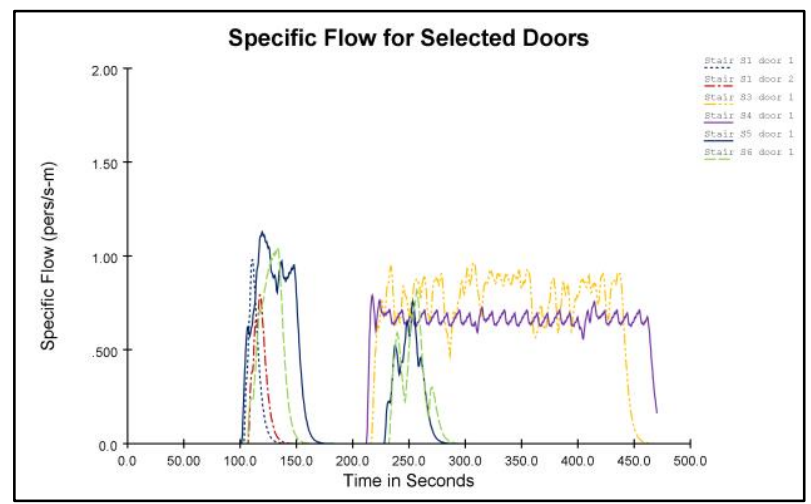

Gambar 18. Grafik specific flow masing-masing tangga

Selaras dengan flow rate maka jumlah penumpang paling banyak melewati pintu D11, D12 dan D15. Sedangkan untuk tangga yang paling banyak digunakan penumpang adalah tangga S3 dan S4.

Dari hasil simulasi didapatkan $\mathrm{T}$ terbesar adalah 470.6 detik, maka pada case siang hari dipakai nilai $\mathrm{E}+\mathrm{L}$ diasumsikan 30 menit sehingga:

$$
\begin{aligned}
& 1.25(\mathrm{~T})+2 / 3(\mathrm{E}+\mathrm{L}) \\
& 1.25 *\left(70^{\prime},\right)+2 / 3(30)=29^{\prime} 48^{\prime},
\end{aligned}
$$

Nilai n yang didapatkan dengan metode advanced evacuation adalah 29 menit 48 detik.

\section{Kesimpulan}

Dari tulisan dan hasil perhitungan studi kasus yang diambil dapat disimpulan bahwa:

1. Dari perhitungan evakuasi pada kapal Ro-ro 5000 GT dengan metode simplified analysis dengan skenario siang hari didapatkan waktu $\mathrm{T}$ 387.2 detik (tanpa faktor pengali 168.37 detik) dan nilai $n$ sebesar 34 menit 19 detik.

2. Dengan advance analysis, simulasi menggunakan pathfinder (SFPE-Basic) didapatkan waktu untuk evakuasi menuju 
embarcation point atau nilai $\mathrm{T}$ adalah 470.6 detik sehingga nilai $n$ sebesar 29 menit 48 detik.

3. Adanya selisih waktu pada kedua metode disebabkan oleh perbedaan pendekatan densitas ruangan, pendekatan interpolasi manual, dan adanya faktor pengali nilai $\mathrm{T}$ sebesar 2.3 pada perhitungan simplified evacuation (sehingga waktu T menjadi besar/over estimate).

4. Penentuan waktu respon (initial delay) pada advance analysis yang berkisar 180 - 240 detik juga mempengaruhi waktu $\mathrm{T}$ hasil simulasi, sehingga diperlukan peneltian lebih detail tentang perilaku penumpang khususnya di beberapa wilayah Indonesia.

5. Bahwa jalur evakuasi baik secara perhitungan simplified dan advance analysis, memenuhi standart IMO MSC/Circ.1238 (dibawah batas maksimum yang diijinkan sebesar 60 menit).

\section{Referensi}

[1] BPTD Wilayah VIII Banten, "Laporan Produksi Pelabuhan Merak 2016", diunduh [07 Februari 2017] melalui http://oppmerak.dephub.go.id/page/profil/1

[2] Kabarbisnis, "Atasi kepadatan arus Merak-Bakauheni, 3 unit kapal Ro-Ro bakal dioperasikan", diunduh [16 Januari 2017] melalui http://www.kabarbisnis.com/read/2849614/atasikepadatan-arus-merak-bakauheni--3-unit-kapal-ro-robakal-dioperasikan.

[3] IMO, "Guidelines for Evacuation Analysis for New and Existing Passenger Ships, MSC.1/Circ.1238", London, 2007.

[4] Pathfinder Thunderhead Engineering, "Pathfinder Verification and Validation”, Manhattan, USA, 2015. 